ANNALS OF "DUNAREA DE JOS" UNIVERSITY OF GALATI

MATHEMATICS, PHYSICS, THEORETICAL MECHANICS

FASCICLE II, YEAR XI (XLII) 2019, No. 2

DOI: https://doi.org/10.35219/ann-ugal-math-phys-mec.2019.2.04

\title{
NON-LINEAR CHARACTERISTICS OF TRANSMISSIBILITY IN THE DYNAMIC RESPONSES OF STANDING SUBJECTS EXPOSED TO VERTICAL WHOLE-BODY VIBRATION
}

\author{
Laurentiu Picu ${ }^{1 *}$, Eugen Rusu ${ }^{2}$ \\ ${ }^{I^{*}}$ Faculty of Engineering and Agronomy in Braila, ,Dunărea de Jos” University of Galati, Romania, \\ e-mail: constantin.picu@ugal.ro \\ ${ }^{2}$ Faculty of Engineering, Mechanical Engineering Department, „Dunărea de Jos” University of Galati, \\ Romania
}

\begin{abstract}
In this paper we studied the action of vibrations with low amplitude and high frequency on the human body, especially on the bone system, because this type of vibration is quite common for some work equipment and the effect on the workers is obvious: predisposition to bones fractures, osteoporosis, etc. For the study of vertical vibrations through the body were used oscillations at amplitudes of $1,1.5$ and $4 \mathrm{~mm}$ and at frequencies between $5 \div 35 \mathrm{~Hz}$. Whole-body vibration measurement was carried out with a NetdB multiple acquisition system using Piezotronics 356A16 PCB triaxial accelerators. Data was processed using dBFA Suite - Purchase and postprocessing data acquisition software. The transmissibility of vibrations to the body was determined as a ratio of the mean square root of the acceleration signal received by the accelerometers $\left(\mathrm{a}_{\mathrm{rms}}\right)$ to the mean square root of the signal acceleration given by the vibrant platform for three regions of the body: the knee, the lumbar region and the forehead. It was found that most $\mathrm{a}_{\mathrm{rms}}$ peaks were obtained for $5 \div 10 \mathrm{~Hz}$ frequencies, but there were also other frequencies for which the maximum was reached, which proves that there are more maximum accelerations specific to the position than those imposed by the vibrant platform. On the other hand, it was also found that the acceleration of transmitted vibration highly decreases compared to the acceleration given by the vibrating platform. There are important differences between the transmissibility of different people, in regard to BMI: it was found that for overweight people, transmissibility is lower than that of the normal ones.
\end{abstract}

Keywords: vibrations, amplitude, frequency, acceleration, transmissibility

\section{INTRODUCTION}

Vibrations act on the human body through the contact surfaces between the human and the vibrant system. The vibrational field can act on the whole body (WBV) (if the person stands or is seated) or on a part of the body, for example on the hands (HAV) [1-3].

Vibrations transmitted to the whole body or just to a part of the body lead to disturbances in the health status of people subjected to the vibrational field $[4,5]$ (fatigue and sleepiness, emotional states of fear or anxiety, headache, diminished attention, decreased visual acuity, changes in tactile sensitivity, respiratory function, blood pressure, nausea, etc.) (Fig.1).

All these negative effects of vibrations on the human body lead to a decrease in the work capacity of the personnel, implicitly reducing its performance [7] work accidents may also occur (Table 1). 


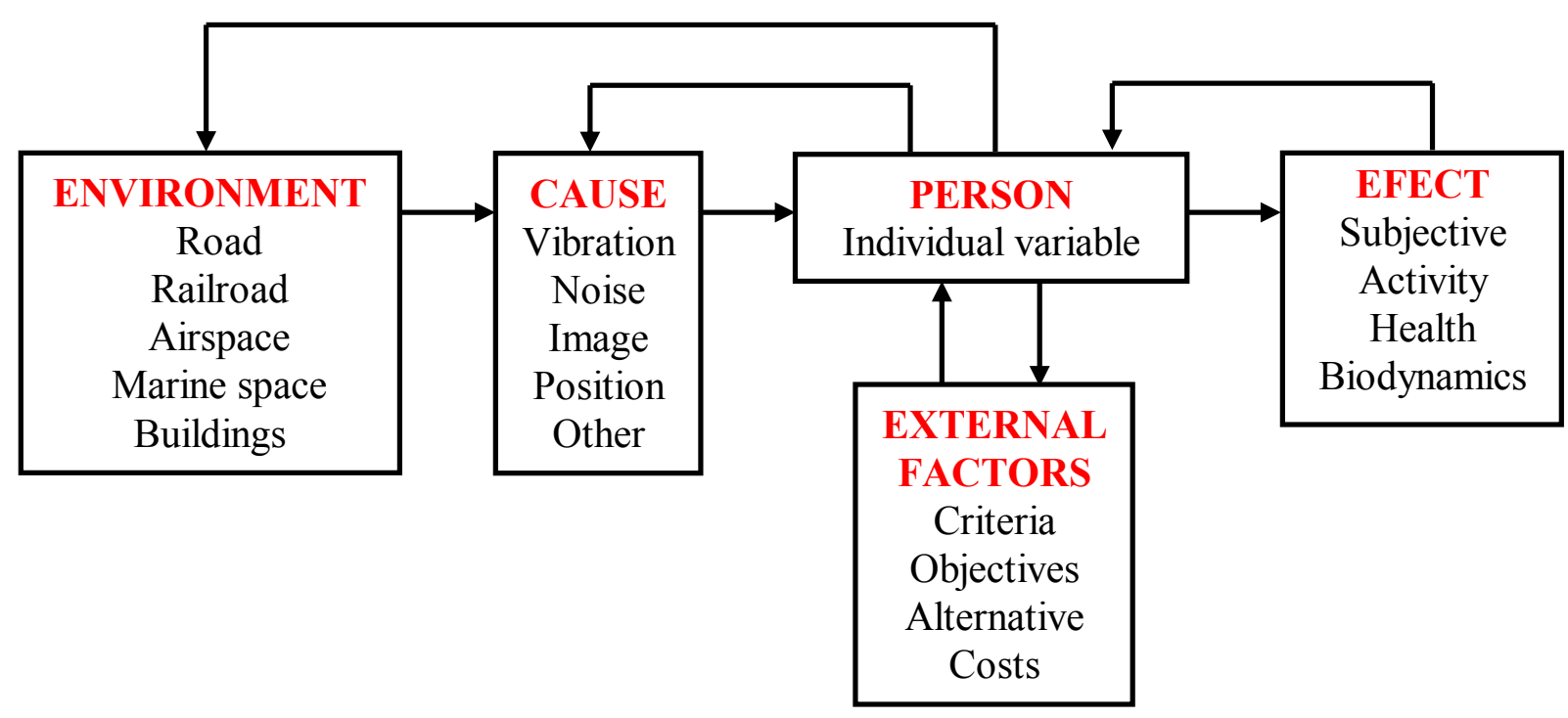

Fig. 1. The model of the relationship between the vibration environment and its effects [6]

Table 1. Variables associated with vibration discomfort

\begin{tabular}{|c|c|c|c|}
\hline \multicolumn{2}{|r|}{ Extrinsic variables } & \multicolumn{2}{|r|}{ Intrinsic variables } \\
\hline \multirow{2}{*}{ 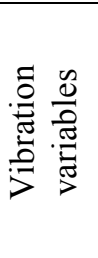 } & $\begin{array}{l}\text { Vibration size and its combinations } \\
\text { Vibration frequency and its combinations } \\
\text { Vibration direction and its combinations }\end{array}$ & 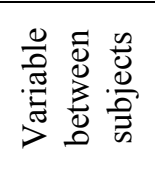 & $\begin{array}{l}\text { Body posture } \\
\text { Body position } \\
\text { Body orientation (lying, sitting, } \\
\text { standing) }\end{array}$ \\
\hline & $\begin{array}{l}\text { Vibration position and combinations } \\
\text { Vibration duration and its combinations }\end{array}$ & \multirow{2}{*}{ 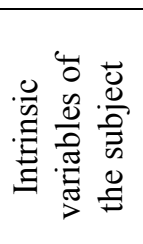 } & $\begin{array}{l}\text { Body size and weight } \\
\text { Age, sex, physical condition }\end{array}$ \\
\hline 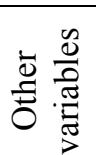 & $\begin{array}{l}\text { Other types of stress (noise, temperature, } \\
\text { etc.) } \\
\text { Seat type }\end{array}$ & & $\begin{array}{l}\text { Experience, personality, attitude } \\
\text { The dynamic response of the body }\end{array}$ \\
\hline
\end{tabular}

The relationship between the vibrations transmitted to the human body and back pain was not yet been fully understood. In this regard, Mansfield and Griffin (2000) [8] analysed „twelve subjects who were exposed to vibrations of six magnitudes, $0.25 \div 2.5 \mathrm{~m} / \mathrm{s}^{2} \mathrm{rms}$. The vertical vibration was in the frequency range of $0.2 \div 20 \mathrm{~Hz}$ ". It was found that "twelve subjects were exposed to six magnitudes, $0.25-2.5 \mathrm{~m} \mathrm{~s}^{-2} \mathrm{rms}$, of vertical random vibration in the frequency range $0.2-20 \mathrm{~Hz}$.

Kiiski et al (2008) [9] subjected four people to vibrations of different amplitudes (from 0.05 to $3 \mathrm{~mm}$ ) and frequencies (from 10 to $90 \mathrm{~Hz}$ ). They mounted accelerometers on different places on the body and analysed the transmission of vibrations to the body.

Ya Huang and Griffin (2009) studied on 12 subjects the resonance frequencies and the transmissibility of vertical vibrations for different frequencies $(0.25 \div 20 \mathrm{~Hz})$ and accelerations $(0.0313$, $0.0625,0.125,0.25,0.5,0.75$ and $1.0 \mathrm{~m} / \mathrm{s}^{2} \mathrm{rms}$ ) for different body positions. A nonlinearity associated with soft tissue response was found [10]. Similar results were also obtained by Harazin in 1998 and Yang et al in $2012[11,12]$.

To deepen the study of human body movement subjected to vibrations, Yoshimura, Nakai and Tamaoki [13] created in 2005 a model with 10 DOFs and studied the vertebrae displacement. 


\section{MATERIALS AND METHODS}

The one who studied in detail the way human body reacts to vibration was Dieckmann in 1958 [14]. Thus, a vibration stress coefficient $\mathrm{k}$ was defined, and it considers the simultaneous influence of frequency and amplitude. Based on physiological and physical studies, Dieckmann also considered the subjects' perception of and obtained for the stress coefficient $\mathrm{k}$ the following equations:

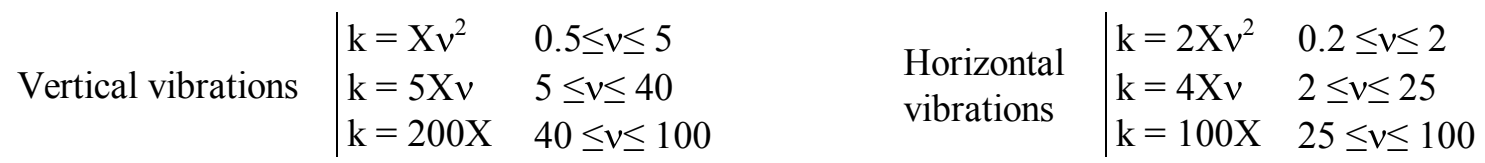

where $\mathrm{X}$ is the displacement peak $(\mathrm{mm})$ and $v$ the frequency.

The threshold of vibration perception corresponds to $\mathrm{k}=0,1$ and at the other end, the permissible limit for $1 \mathrm{~min}$ is given by $\mathrm{k}=100$. These values are also presented in DIN 4024: 2001. Figures 2 and 3 show amplitude and acceleration variations of vertical and horizontal vibrations in relation to frequency and stress coefficient $\mathrm{k}[15]$.

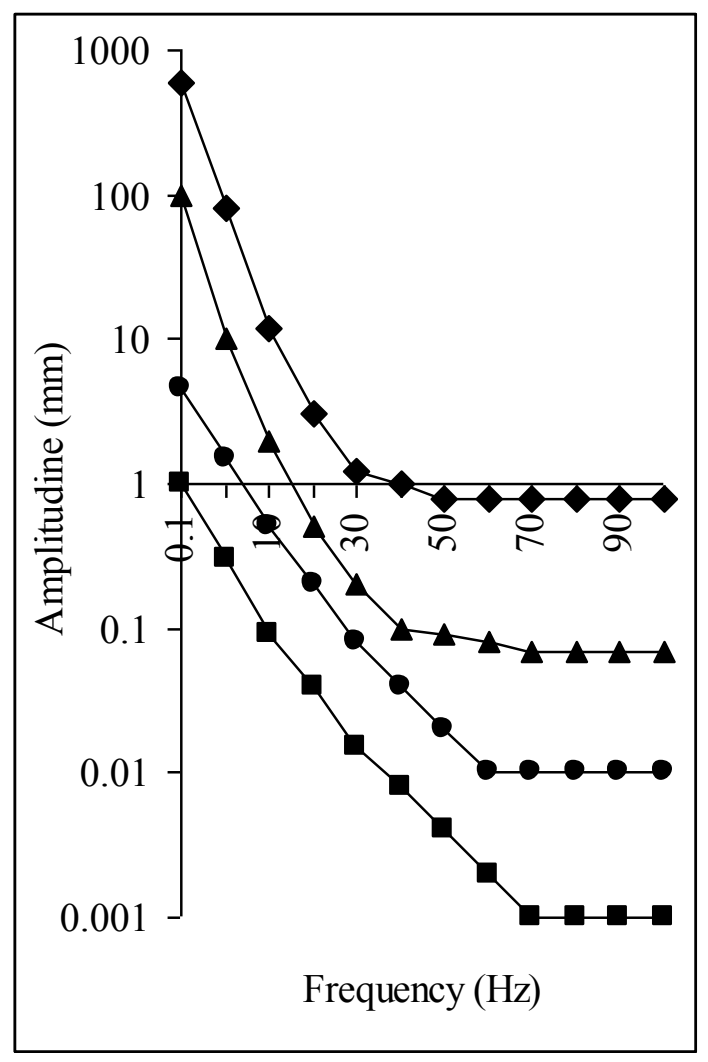

Fig. 2. Amplitude variation with frequency depending on vibration stress coefficient $k$

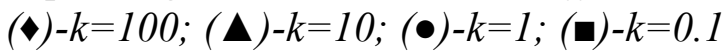

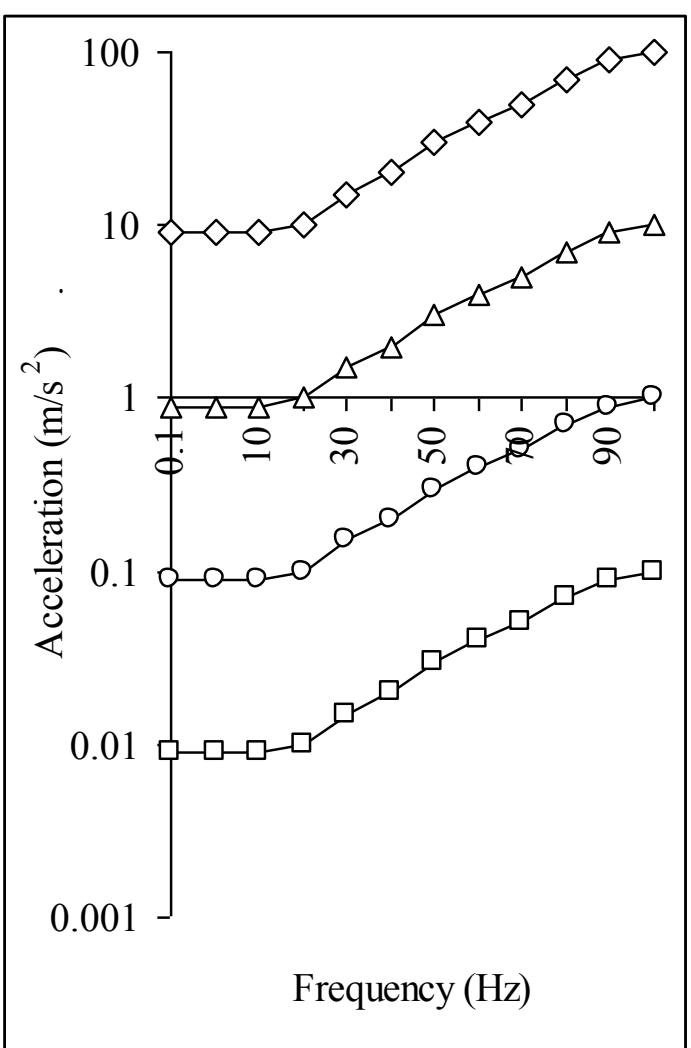

Fig. 3. Acceleration variation with frequency depending on vibration stress coefficient $k$ $(\diamond)-k=100 ;(\Delta)-k=10 ;(o)-k=1$; ( $)-k=0.1$

The coefficient $\mathrm{k}$ can be found depending on the effective acceleration r.m.s, the effective speed r.m.s. and the effective displacement r.m.s.. The values of the constants $\alpha, \beta$ and $\gamma$ are given directly in the formulas, and $v_{0}=10 \mathrm{~Hz}[15]$ : 


$$
\begin{aligned}
& \mathrm{k}=\mathrm{a}_{\mathrm{ef}} \frac{\alpha}{\sqrt{1+\left(\frac{v}{v_{0}}\right)^{2}}}=\mathrm{a}_{\mathrm{ef}} \frac{18}{\sqrt{1+\left(\frac{v}{10}\right)^{2}}}=\mathrm{a}_{\mathrm{ef}} \frac{180}{\sqrt{100+v^{2}}} \\
& \mathrm{k}=\mathrm{v}_{\mathrm{ef}} \frac{\beta \cdot \mathrm{v}}{\sqrt{1+\left(\frac{v}{v_{0}}\right)^{2}}}=\mathrm{v}_{\mathrm{ef}} \frac{0,112 \cdot v}{\sqrt{1+\left(\frac{v}{10}\right)^{2}}}=\mathrm{v}_{\mathrm{ef}} \frac{1,12 \cdot v}{\sqrt{100+v^{2}}} \\
& \mathrm{k}=\mathrm{x}_{\mathrm{ef}} \frac{\gamma \cdot v^{2}}{\sqrt{1+\left(\frac{v}{v_{0}}\right)^{2}}}=\mathrm{x}_{\mathrm{ef}} \frac{0,71 \cdot v^{2}}{\sqrt{1+\left(\frac{v}{10}\right)^{2}}}=\mathrm{x}_{\mathrm{ef}} \frac{7,1 \cdot v^{2}}{\sqrt{100+v^{2}}}
\end{aligned}
$$

The $\mathrm{k}$ coefficient was also determined by the acceleration peak $\mathrm{A}\left(\mathrm{mm} / \mathrm{s}^{2}\right)$, the velocity peak $\mathrm{V}$ $(\mathrm{mm} / \mathrm{s})$ and the displacement peak $X(\mathrm{~mm})$. The constant values are directly given in equations, and $v_{0}=10 \mathrm{~Hz}[6,14]$.

$$
\begin{aligned}
& \mathrm{k}=\mathrm{A} \frac{12,5}{\sqrt{1+\left(\frac{v}{10}\right)^{2}}}=\mathrm{A} \frac{125}{\sqrt{100+v^{2}}} \\
& \mathrm{k}=\mathrm{V} \frac{0,08 \cdot \mathrm{v}}{\sqrt{1+\left(\frac{v}{10}\right)^{2}}}=\mathrm{V} \frac{0,8 \cdot \mathrm{v}}{\sqrt{100+v^{2}}} \\
& \mathrm{k}=\mathrm{X} \frac{0,5 \cdot \mathrm{v}^{2}}{\sqrt{1+\left(\frac{v}{10}\right)^{2}}}=X \frac{5 \cdot v^{2}}{\sqrt{100+v^{2}}}
\end{aligned}
$$

According to Griffin [6], in Table 2 are shown the values of $\mathrm{k}$ for which vibrations are tolerable. These tolerances are valid for discontinuous vibrations:

Table 2. Values of $\mathrm{k}$ for which vibrations are tolerable

\begin{tabular}{rll}
\hline \multicolumn{2}{c}{$\mathbf{k}$} & \\
\hline 0.1 & $\ldots .$. & Initial threshold \\
0.25 & $\ldots \ldots$. & You can live with small breaks, or even without breaks \\
0.63 & $\ldots \ldots$. & You can live with breaks \\
1,6 & $\ldots \ldots$. & You can work without breaks \\
4 & $\ldots \ldots$. & You can work with small breaks \\
10 & $\ldots \ldots$. & You can work with long breaks \\
25 & $\ldots \ldots$. & You can travel for long periods \\
63 & $\ldots \ldots$. & You can travel for short periods \\
\hline
\end{tabular}


To verify how vibrations are transmitted through the human body and how the body mass index influences this, the following experiment was made: 10 subjects (males) were placed on the vibrant system (Fig. 4); men were approximately the same age (22-25 years) and in good health; none of them constantly practice sports and have sedentary jobs; 5 of these men are normal and 5 are pre-obese (Fig. 5).

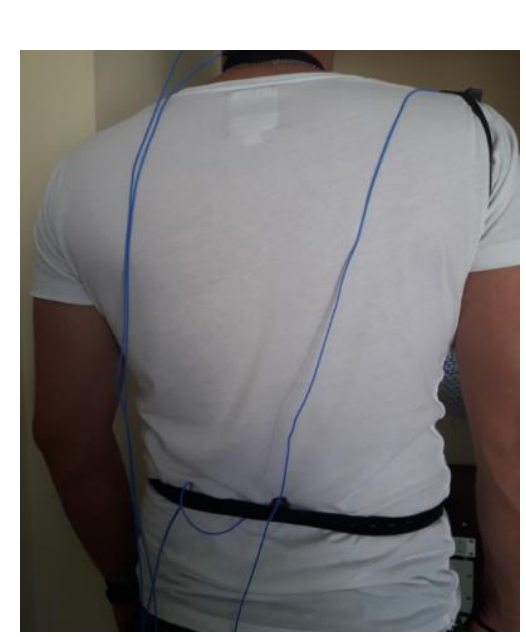

accelerometer on lumbar

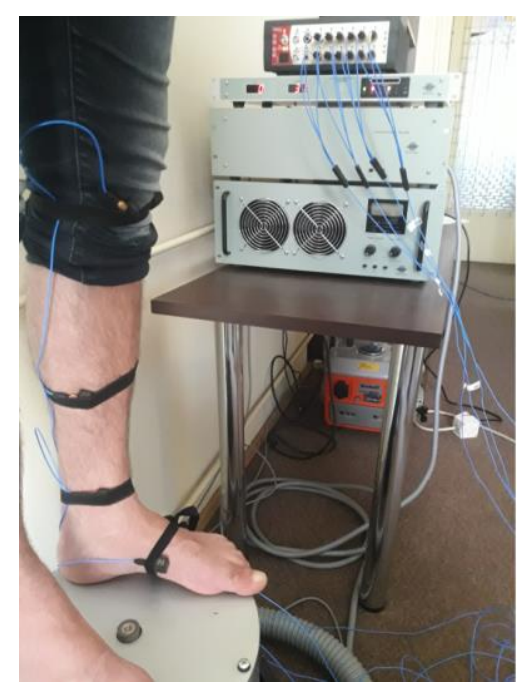

accelerometer on knee

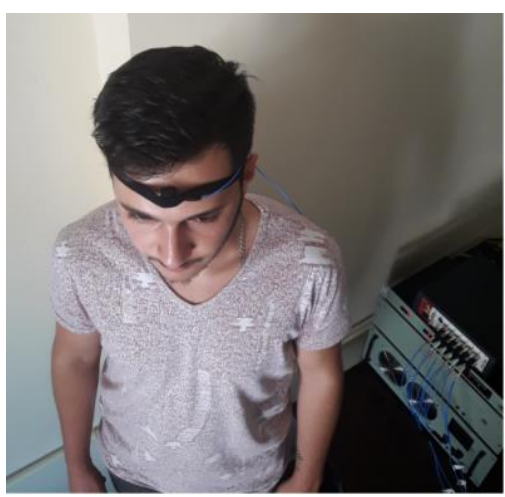

accelerometer on forehead

Fig. 4. Normal subject on vibrant system

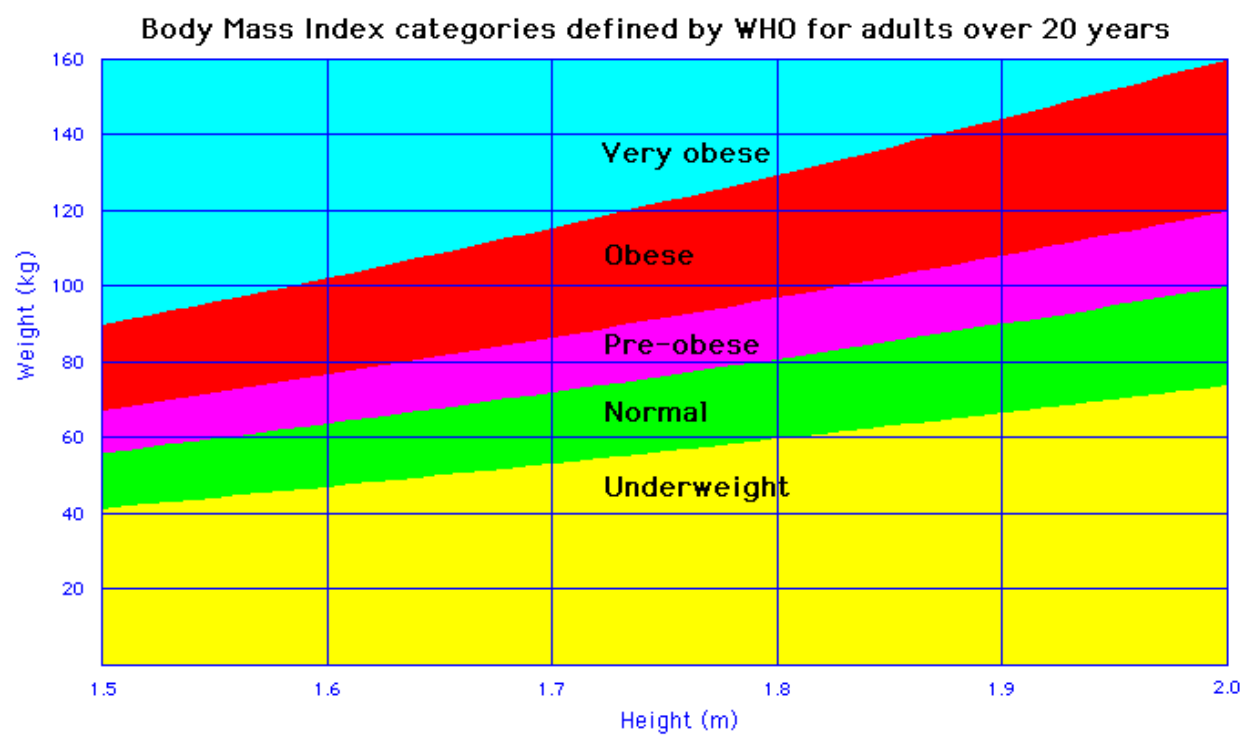

Fig. 5. Body mass index (http://links.zero.eu.org/health/bmi/)

The vibrant system was set to vibrate at frequencies between $5 \div 35 \mathrm{~Hz}$ (dangerous frequencies for the human body) and amplitudes $\mathrm{A}=1 ; 1.5$ and $4 \mathrm{~mm}$. The irradiation time was in all cases $5 \mathrm{~min}$. Accelerometers were mounted on the knee, in the lumbar region and on the forehead (Fig. 4). Transmissibility was calculated as the ratio between the acceleration measured with the accelerometer $\left(a_{\text {meas }}\right)$ and the acceleration of the vibrating system $\left(a_{\text {v.s. }}\right)$.

$$
\mathrm{T}=\frac{\mathrm{a}_{\text {meas }}}{\mathrm{a}_{\mathrm{v} . \mathrm{s}}}
$$




\section{RESULTS AND DISCUSSION}

Tables 3 and 4 present the measurement results and the calculations made with http://www.hse.gov.uk/vibration/wbv/calculator.htm of the specific physical quantities in the case of vibration transmission from the oscillating vibration system with an acceleration of $4 \mathrm{~m} / \mathrm{s}^{2}$, in frequency band 5-35Hz. Normal subjects (Table 3 ) and pre-obese subjects (Table 4) are subjected to vibration for 5 minutes and accelerometers are placed on the forehead.

Table 3. The measurement results and calculations of the specific physical quantities of vibrations in the case of normal subjects

\begin{tabular}{|c|c|c|c|c|c|c|}
\hline $\begin{array}{l}\text { HSE } \\
\text { Vibration } \\
\text { magnitude } \\
\text { r.m.s. } \\
\mathrm{m} / \mathrm{s}^{2}\end{array}$ & $\begin{array}{l}\text { Exposure } \\
\text { duration }\end{array}$ & $\begin{array}{l}\text { Partial } \\
\text { VDV }\end{array}$ & $\begin{array}{c}\text { Partial } \\
\text { exposure } \\
\mathbf{A}(8)\end{array}$ & $\begin{array}{c}\text { Time to reach } \\
\text { EAV } \\
\text { (VDV option) } \\
9.1 \mathrm{~m} / \mathbf{s}^{1.75} \\
\text { hours }\end{array}$ & $\begin{array}{c}\text { Time to reach } \\
\text { EAV } \\
\text { (A(8) option) } \\
0.5 \mathrm{~m} / \mathbf{s}^{\mathbf{2}} \\
\\
\text { hours }\end{array}$ & $\begin{array}{c}\text { Time to reach } \\
\text { ELV } \\
\text { (A(8) option only) } \\
1.15 \mathrm{~m} / \mathrm{s}^{2} \\
\text { hours }\end{array}$ \\
\hline 3.125 & 5 & 18.2078 & 0.32 & 0.0051994 & 0.2048 & 1.08 \\
\hline 3.159 & 5 & 18.4059 & 0.32 & 0.0049791 & 0.20042 & 1.06 \\
\hline 3.242 & 5 & 18.8895 & 0.33 & 0.0044885 & 0.19028 & 1.01 \\
\hline 3.164 & 5 & 18.4351 & 0.32 & 0.0049477 & 0.19978 & 1.06 \\
\hline 3.244 & 5 & 18.9 & 0.33 & 0.0044774 & 0.19 & 1.01 \\
\hline
\end{tabular}

Table 4. The measurement results and calculations of the specific physical quantities of vibrations in the case of pre-obese subjects

\begin{tabular}{|c|c|c|c|c|c|c|}
\hline $\begin{array}{c}\mathrm{HSE} \\
\text { Vibration } \\
\text { magnitude } \\
\text { r.m.s. } \\
\mathrm{m} / \mathrm{s}^{2}\end{array}$ & $\begin{array}{c}\text { Exposure } \\
\text { duration }\end{array}$ & $\begin{array}{c}\text { Partial } \\
\text { VDV }\end{array}$ & $\begin{array}{c}\text { Partial } \\
\text { exposure } \\
\mathbf{A}(8)\end{array}$ & $\begin{array}{c}\text { Time to reach } \\
\text { EAV } \\
\text { (VDV option) } \\
9.1 \mathrm{~m} / \mathrm{s}^{1.75} \\
\text { hours }\end{array}$ & $\begin{array}{l}\text { Time to reach } \\
\text { EAV } \\
\text { (A(8) option) } \\
0.5 \mathrm{~m} / \mathrm{s}^{2}\end{array}$ & $\begin{array}{c}\text { Time to reach } \\
\text { ELV } \\
\text { (A(8) option only) } \\
1.15 \mathrm{~m} / \mathrm{s}^{\mathbf{2}} \\
\text { hours }\end{array}$ \\
\hline 2.845 & 5 & 16.5764 & 0.29 & 0.0075687 & 0.2471 & 1.31 \\
\hline 2.796 & 5 & 16.2909 & 0.29 & 0.0081134 & 0.25583 & 1.35 \\
\hline 2.879 & 5 & 16.7745 & 0.29 & 0.0072175 & 0.24129 & 1.28 \\
\hline 2.992 & 5 & 17.4329 & 0.31 & 0.0061873 & 0.22341 & 1.18 \\
\hline 2.744 & 5 & 16 & 0.28 & 0.0087461 & 0.266 & 1.41 \\
\hline
\end{tabular}

It is found that for normal subjects, the average for Time to reach EAV $(\mathrm{A}(8)$ option $)=$ $0.197056 \mathrm{~h}$ and for Time to reach ELV (A(8) option only) $=1.044 \mathrm{~h}$, while for pre-obese subjects, these averages are higher: $0.246726 \mathrm{~h}$, respectively $1.306 \mathrm{~h}$.

In figures 6 and 7 are shown total VDV calculation and total exposure $\mathrm{A}(8)$ calculation, where it can be seen that for normal subjects, total VDV calculation is $11.66 \%$ higher than for pre-obese subjects. The same result is also obtained for the total exposure $\mathrm{A}(8)$ calculation that is higher in normal subjects with $11.73 \%$ as against pre-obese subjects. 


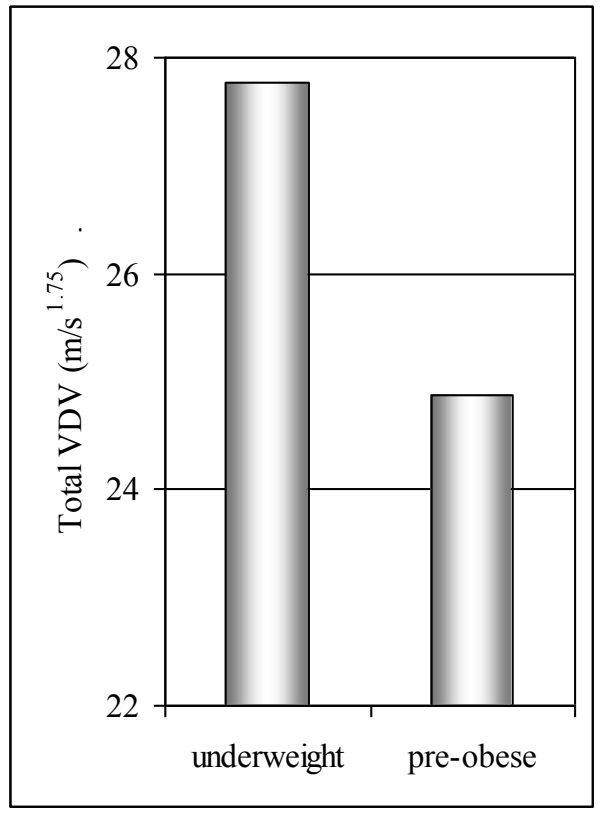

Fig. 6. Total VDV

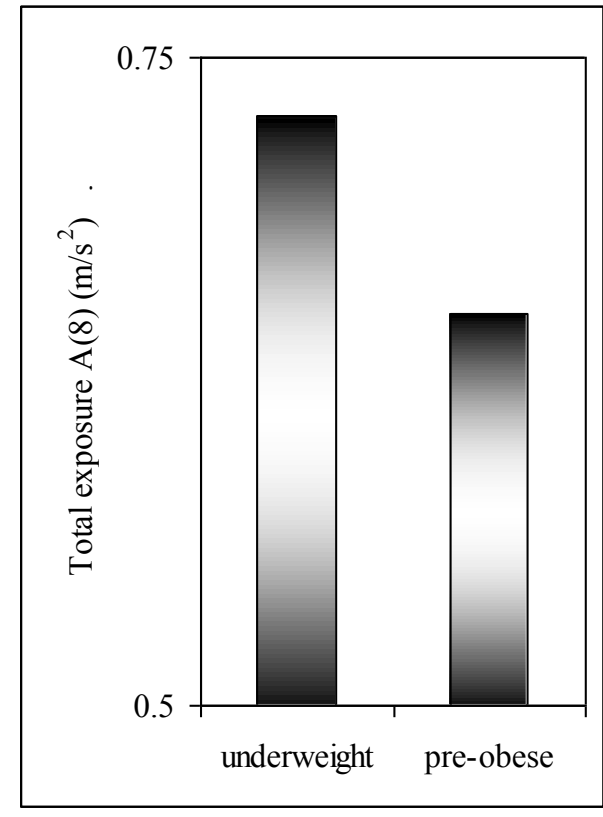

Fig. 7. Total exposure A(8)

Regarding transmissibility, it was calculated with Eq (7) for the three analysed situations: with accelerometers on the knee, on the lumbar region and on the forehead. Graphic representations of these are shown in Figures 8, 9 and 10.

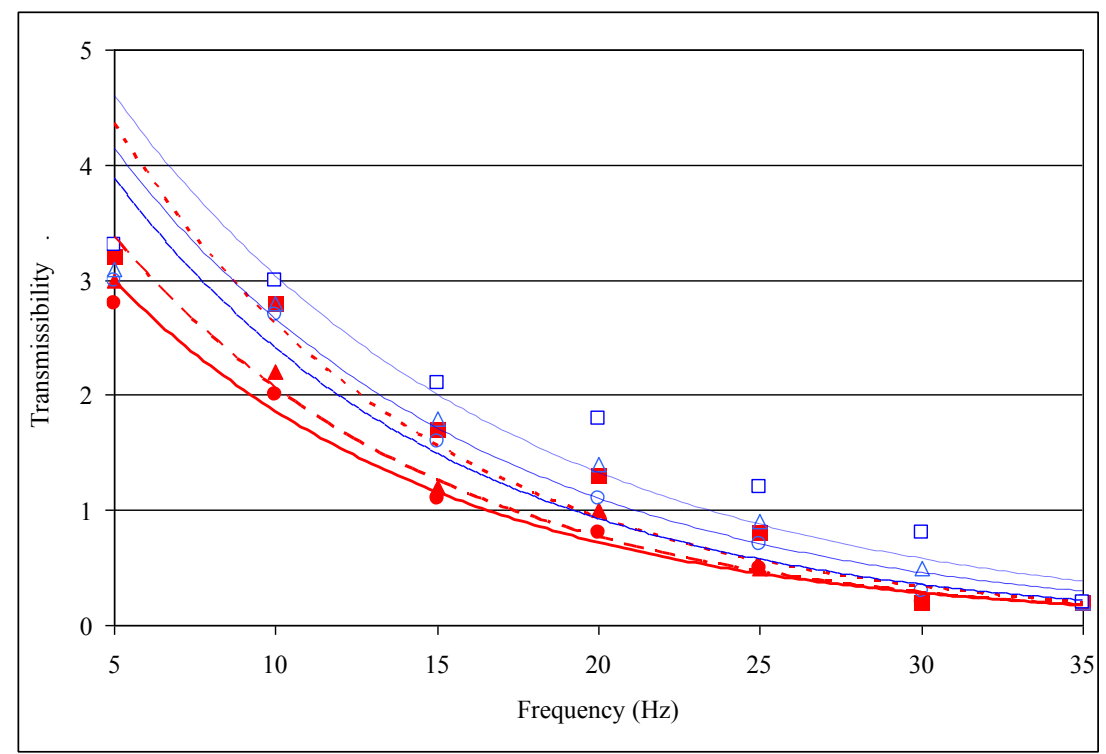

Fig. 8. Transmissibility variation on the frequency band $5 \div 35 \mathrm{~Hz}$ for the 3 amplitudes $A=1 \mathrm{~mm}, 1.5 \mathrm{~mm}$ and $4 \mathrm{~mm}$, on the knee

For average $\mathrm{BMI}=26.12$ (pre-obese subjects)

$$
\begin{aligned}
& \mathrm{A}=1 \mathrm{~mm} \\
& \text { - } \\
& \mathrm{T}=4.8092 \cdot \mathrm{e}^{-0.0951 \cdot v} \\
& \mathrm{R}^{2}=0.9745 \\
& \mathrm{~A}=1.5 \mathrm{~mm} \\
& \Delta-\text { - } \\
& \mathrm{A}=4 \mathrm{~mm} \\
& \text {-... } \\
& \mathrm{T}=5.5154 \cdot \mathrm{e}^{-0.0985 \cdot v} \quad \mathrm{R}^{2}=0.9658 \\
& \mathrm{~T}=5.7469 \cdot \mathrm{e}^{-0.1005 \cdot v} \\
& \mathrm{R}^{2}=0.9356
\end{aligned}
$$

For average $\mathrm{BMI}=18.27$ (normal subjects)

$$
\begin{array}{ccc}
\mathrm{A}=1 \mathrm{~mm} & \mathrm{~T}=6.2538 \cdot \mathrm{e}^{-0.0953 \cdot v} & \mathrm{R}^{2}=0.9706 \\
\mathrm{o}--- & & \\
\mathrm{A}=1.5 \mathrm{~mm} & \mathrm{~T}=6.4408 \cdot \mathrm{e}^{-0.0883 \cdot v} & \mathrm{R}^{2}=0.9384 \\
\begin{array}{c}
\Delta--- \\
\mathrm{A}=4 \mathrm{~mm}
\end{array} & \mathrm{~T}=6.9639 \cdot \mathrm{e}^{-0.083 \cdot v} & \mathrm{R}^{2}=0.8531 \\
\square \ldots & &
\end{array}
$$




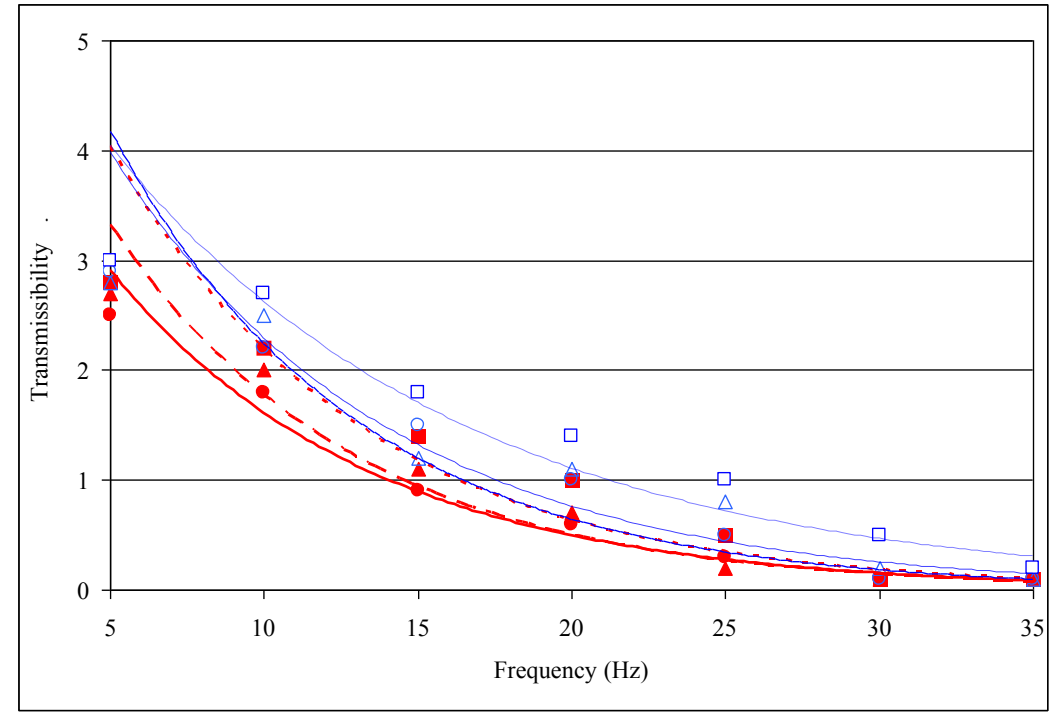

Fig. 9. Transmissibility variation on the frequency band $5 \div 35 \mathrm{~Hz}$ for the 3 amplitudes $A=1 \mathrm{~mm}, 1.5 \mathrm{~mm}$ and $4 \mathrm{~mm}$, on the lumbar region

For average $\mathrm{BMI}=26.12$ (pre-obese subjects)

\begin{tabular}{|c|c|c|}
\hline $\mathrm{A}=1 \mathrm{~mm}$ & $\mathrm{~T}=5.2554 \cdot \mathrm{e}^{-0.1181 \cdot v}$ & $\mathrm{R}^{2}=0.9716$ \\
\hline $\begin{array}{l}\mathrm{A}=1.5 \mathrm{~mm} \\
-\mathbf{Z}\end{array}$ & $\mathrm{T}=6.2198 \cdot \mathrm{e}^{-0.1256 \cdot v}$ & $\mathrm{R}^{2}=0.9585$ \\
\hline $\mathrm{A}=4 \mathrm{~mm}$ & $\mathrm{~T}=4.8159 \cdot \mathrm{e}^{-0.1188 \cdot v}$ & $\mathrm{R}^{2}=0.9166$ \\
\hline
\end{tabular}

For average $\mathrm{BMI}=18.27$ (normal subjects)

$$
\begin{array}{ccc}
\mathrm{A}=1 \mathrm{~mm} & \mathrm{~T}=7.76 \cdot \mathrm{e}^{-0.1242 \cdot v} & \mathrm{R}^{2}=0.9236 \\
\mathrm{o}--- & & \\
\mathrm{A}=1.5 \mathrm{~mm} & \mathrm{~T}=6.921 \cdot \mathrm{e}^{-0.1104 \cdot v} & \mathrm{R}^{2}=0.911 \\
\begin{array}{c}
\Delta--- \\
\mathrm{A}=4 \mathrm{~mm}
\end{array} & \mathrm{~T}=6.2235 \cdot \mathrm{e}^{-0.0863 \cdot v} & \mathrm{R}^{2}=0.9231 \\
\square \ldots & \ldots &
\end{array}
$$

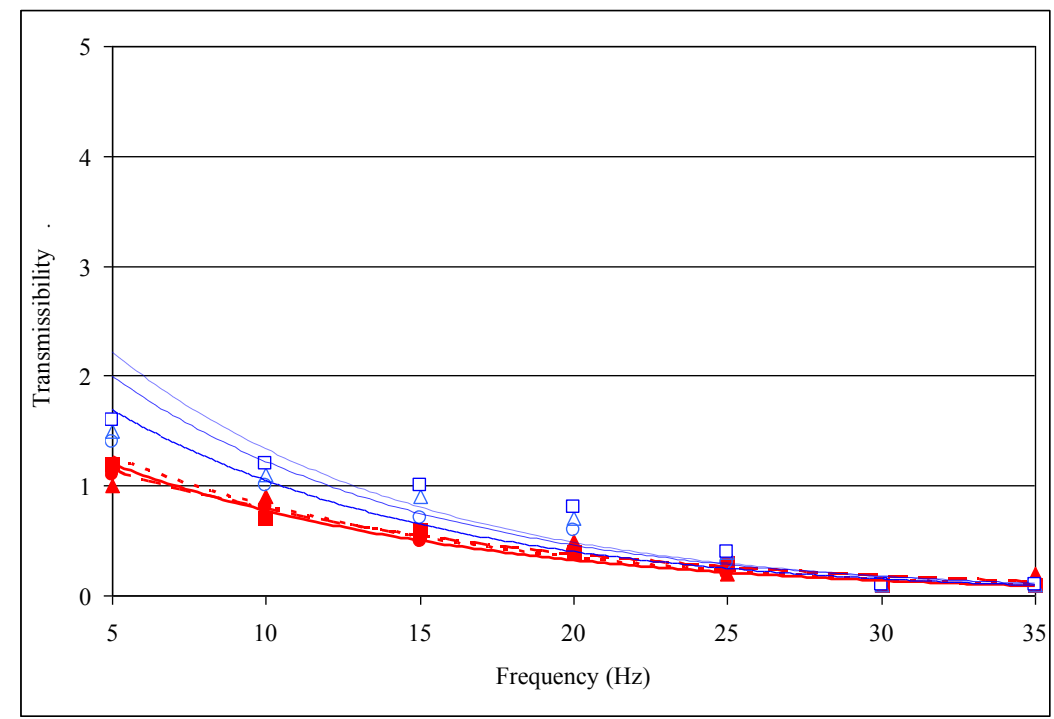

Fig. 10. Transmissibility variation on the frequency band $5 \div 35 \mathrm{~Hz}$ for the 3 amplitudes $A=1 \mathrm{~mm}, 1.5 \mathrm{~mm}$ and $4 \mathrm{~mm}$, on the forehead

For average $\mathrm{BMI}=26.12$ (pre-obese subjects)

$$
\begin{aligned}
& \mathrm{A}=1 \mathrm{~mm} \\
& \mathrm{~A}=\overline{1.5 \mathrm{~mm}} \\
& \text { A - - } \\
& \mathrm{T}=1.8528 \cdot \mathrm{e}^{-0.0876 \cdot \mathrm{v}} \\
& \mathrm{R}^{2}=0.9704 \\
& \mathrm{~T}=1.6465 \cdot \mathrm{e}^{-0.0737 \cdot v} \\
& \mathrm{R}^{2}=0.8327
\end{aligned}
$$

For average $\mathrm{BMI}=18.27$ (normal subjects) $\begin{array}{ccc}\mathrm{A}=1 \mathrm{~mm} & \mathrm{~T}=2.7297 \cdot \mathrm{e}^{-0.0955 \cdot v} & \mathrm{R}^{2}=0.9371 \\ \mathrm{o}--- & & \\ \mathrm{A}=1.5 \mathrm{~mm} & \mathrm{~T}=3.2489 \cdot \mathrm{e}^{-0.0981 \cdot v} & \mathrm{R}^{2}=0.9025 \\ \Delta--- & \end{array}$ 


$$
\begin{array}{cc|ccc}
\mathrm{A}=4 \mathrm{~mm} & \mathrm{~T}=1.9373 \cdot \mathrm{e}^{-0.086 \cdot v} & \mathrm{R}^{2}=0.9466 & \begin{array}{c}
\mathrm{A}=4 \mathrm{~mm} \\
\square \ldots
\end{array} & \mathrm{T}=3.6754 \cdot \mathrm{e}^{-0.1015 \cdot v} \quad \mathrm{R}^{2}=0.8959
\end{array}
$$

From these graphics it is clear that for pre-obese people transmissibility is lower than for the normal people. Also, it is found that transmissibility exponentially decreases with the frequency increase of the vibrant system.

i) In the first case (measurements made at knee level), the term in front of the exponential has close values, ranging from $4.8 \div 5.7$ for pre-obese subjects, respectively between $6.2 \div 6.9$ for normal subjects.

ii) In the second case (measurements made at the lumbar region), the term in front of the exponential also has close values, ranging from $4.8 \div 6.2$ for pre-obese subjects, respectively between $6.2 \div 7.7$ for normal subjects.

iii) In the third case (measurements made on the forehead) the term in front of the exponential has close values, ranging from $1.6 \div 1.9$ for pre-obese subjects, respectively $2.7 \div 3.6$ for normal subjects.

The clearest delimitation between the transmissibility values for pre-obese and normal subjects is seen in the measurements made with the accelerometer mounted on the forehead.

As for the exponential powers, these are within a very narrow range: $0.07 \div 0.12$ (both extremes are encountered in pre-obese subjects) (Fig. 11).

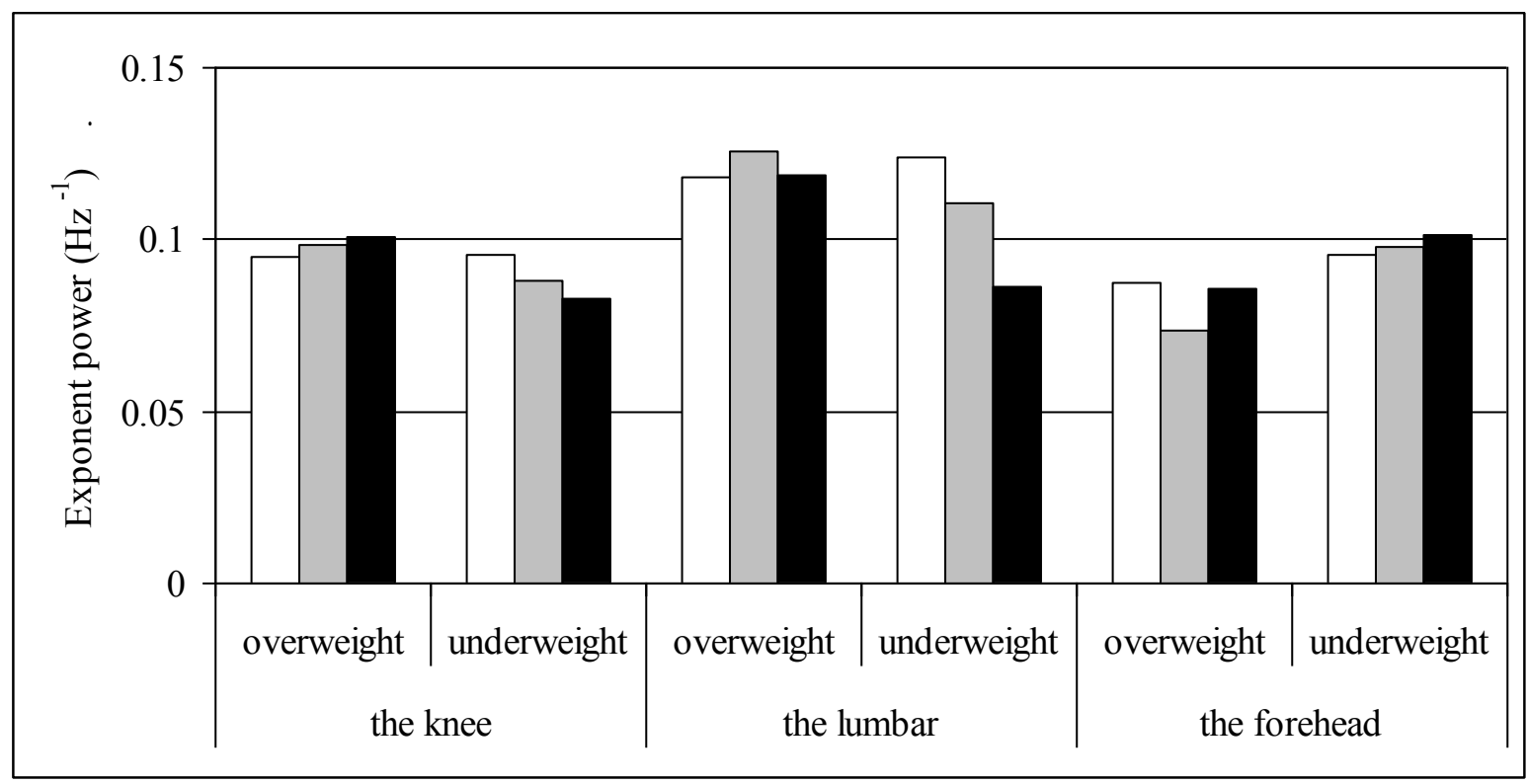

Fig. 11. Variation of exponential powers on the position of the accelerometers, vibration amplitude and $B M I$ () $-A=1 \mathrm{~mm}$; ( $)-A=1.5 \mathrm{~mm}$; (ロ) $-A=4 \mathrm{~mm}$

\section{CONCLUSIONS}

From those presented in this paper, it can be seen that - for the studied cases - the dependence of vibrations transmissibility on frequency is strictly exponential decreasing. It is also seen that waves transmissibility is strongly dependent on BMI; for overweight people, transmissibility is lower than for normal people. In addition, transmissibility is also dependent on the magnitude of the waves. In other words, the transmissibility of elastic waves depends on the wave parameters, but also on the individual characteristics of each individual.

Acknowledgment: This work was carried out in the framework of the research project REMARC (Renewable Energy extraction in MARine environment and its Coastal impact), supported by the 
Romanian Executive Agency for Higher Education, Research, Development and Innovation Funding UEFISCDI, grant number PN-III-P4-IDPCE-2016-001.

\section{References}

1. Picu, L., Rusu, E.V.C., Whole body vibrations of a pushtow boat crew on the Danube, Mechanical Testing and Diagnosis, ISSN 2247-9635, 2017 (VII), Volume 1, pp 28-35.

2. Picu, M., Picu, L., Particular aspects regarding the effects of whole body vibration exposure, International Conference on Engineering Vibration, Sofia (ICoEV 2017), Bulgaria, 4-7 September 2017, MATEC Web Conf., 148 (2018) 09005, DOI: https://doi.org/10.1051/matecconf/201814809005.

3. Picu, L., Biodynamics of the Human Body under Hand-Arm Vibration: Development of a Biomechanical Model, The $11^{\text {th }}$ European Congress and Exposition on Noise Control Engineering, (Euronoise 2018), Hersonissos, Crete, 27-31 May 2018, Conference Proceedings, pp 2663-2668.

4. Palmer, K.T., Coggon, D.N., Bendall, H.E., Pannett, B., Griffin, M., Haward, B., Whole-body Vibration: Occupational Exposures and their Health Effects in Great Britain. HSE Contract Research Report 233/1999, London: HMSO.

5. Picu, L., Rusu, E.V.C., Multiple physical stress exposures of sailors on several ships - A longitudinal study, Annals of Dunarea de Jos University, Fascicle II-Mathematics, Physics, Theoretical Mechanics, ISSN 2067-2071, Year X(XLI) 2018, No. 1, pp 84-93.

6. Griffin, M.J., Handbook of Human Vibration, San Diego CA: Academic Press Inc, 1990.

7. Picu, L., Picu, M., Rusu, E.V.C., Evaluation of Human Exposure to Whole-Body Vibration Verification Method of Stevens's Power Law, The $18^{\text {th }}$ International Multidisciplinary Scientific GeoConference (SGEM 2018), Albena, Bulgaria, 30 June - 9 July 2018, Conference Proceedings Vol. 18, Issue: 5.2 , pp 413-420, DOI: $10.5593 /$ sgem2018/5.2/S20.055.

8. Mansfield, N.J., Griffin, M.J., Non-linearities in apparent mass and transmissibility during exposure to whole-body vertical vibration, Journal of Biomechanics, Volume 33, Issue 8, August 2000, pp 933 941.

9. Kiiski, J., Heinonen, A., Järvinen, T.L., Kannus, Pe., Sievänen, H., Transmission of Vertical Whole Body Vibration to the Human Body, Journal of Bone and Mineral Research, Vol. 23, Nr. 8, 2008.

10. Huang, Y., Griffin, M.J., Nonlinearity in apparent mass and transmissibility of the supine human body during vertical whole-body vibration, Journal of Sound and Vibration, Volume 324, Issues 1-2, 10 July 2009, pp 429-452.

11. Harazin, B., Grzesik, J., The Transmission of Vertical Whole-Body Vibration to the Body Segments of Standing Subjects, Journal of Sound and Vibration, Volume 215, Issue 4, 27 August 1998, pp 775787.

12. Yang, L., Gong, H., Zhang, M., Transmissibility of Whole Body Vibration Stimuli Through Human Body in Different Standing Postures, Journal of Mechanics in Medicine and Biology, Vol. 12, No. 03, 2012.

13. Yoshimura, T., Nakai, K., Tamaoki, G., Multi-body Dynamics Modelling of Seated Human Body under Exposure to Whole-Body Vibration, Industrial Health, 43, 2005.

14. Dieckmann, D., A study of the influence of vibration on man, Ergonomics, Vol. 1, Issue 4, 1958, 347 355, 1958.

15. Bratu, P., Izolarea și amortizarea vibrațiilor la utilaje de construcții, Ed. INCERC, București, 1982. 